\title{
Housing the Multitude: Struggling with Impermanence and Singularities
}

\author{
Xavier Van Rooyen, Michaël Bianchi
}

CRITICISM

\begin{abstract}
This article seeks to trace a history of Team X's experimentations on the issue of housing for the great number and more specifically around the theoretical background leading to the question of impermanence and indeterminacy in the architectural process. Through the writings of the Smithsons, Oskar Hansen, or John Voelcker, a theoretical framework will be defined and then put into perspective in a contemporary context. Two case studies will be discussed: Lacaton \& Vassal, and Elemental. Connections will be made on the issue of indeterminacy and the concepts of "open structure" and "open aesthetics" will be promoted. These concepts presented here offer an alternative for some other possible formal developments around the question of indeterminacy. We will assess whether the pragmatism of these two contemporary architectural offices allow their proposals, beyond responding to specific situations, to claim the status of a reproducible model, such as one imagined during the 1960 s.
\end{abstract}

Keywords: extra space, impermanence, indeterminacy, open aesthetics, open structure

In England, during the reconstruction phase following the destruction of the Second World War, housing was one of the main pillars of the Welfare State. ${ }^{1}$ The urgency of the housing issue in this post-war context has contributed to the commitment of architects to theorizing and experimenting on the housing model for "the great number." ${ }^{2}$ Among the first manifestations of these concerns by architects are the proposals of the GAMMA group, led by George Candilis, with their project for the 
Carrières Centrales in Casablanca as an illustration. The question of the "greatest number" was also taken up by the architects grouped within Team $X$, who made housing the focus of their first experiments. In the fifteen years since Team $X$ was founded, this housing issue has been linked to the postwar economic expansion context. In this rapidly changing society, these architects were led to theorize the adaptability over time of their models, by introducing the question of indeterminacy into the heart of architectural design.

At the turn of the oil crisis in the 1970s, these expansionist architectural models, designed for mass urbanization, were strongly criticized and questioned, particularly by Alison and Peter Smithson, active members of Team X. In a 1974 article, Alison Smithson acknowledged the failure of the occupants to receive their Robin Hood Gardens project, a project located in a working-class district of London and completed in 1972. In particular, it deduced from this the need for individualization of housing, which was not present in the design of the project. This observation is illustrative of the failure of the theoretical models produced in the 1950s and 1960s to effectively embody themselves in the constructed reality. Beyond some heroic achievements, these models have not succeeded in significantly influencing constructed reality and mass urbanization. The theory did not succeed in embodying itself, and the proposed models were classified in the category of utopias.

Shortly afterwards, England experienced the Thatcher era and the gradual destruction of the principles of the Welfare state, ending a rich period of theoretical and constructive exploration. In 1989, the English government definitively delegated to private markets "the responsibility for affordable housing provisions to the markets." ${ }^{3}$

In an issue of OASE, in September 2011, the question of indeterminacy in architecture resurfaces. The editorial in this issue notes that, in the context of continued economic instability since the 2008 financial crisis, rapid changes in political, social and economic parameters weakened architectural design, which is generally established over time. This observation updated the need to integrate the parameter of indeterminacy into the architectural design, following the example of the concerns developed by radical architects in the $1960 \mathrm{~s},{ }^{4}$ but in an economic context of recession and not of expansion. In addition to this economic instability, the ecological issue has gradually become a major concern for public policies. In architecture, it introduced the need for a less resource-intensive construction, and in particular the need to avoid emollitions/reconstructions, which are costly in terms of energy and produce large quantities of waste and significant nuisances in urban areas. The question of collective housing addresses these issues head-on: how can we develop housing and urbanization methods that are viable in the long term, but that take into account the impermanence of means, needs and desires, and the economic, cultural and aesthetic specificities of their successive users? 
Are there now, as in the 1960s, attempts to produce housing models that respond to this search for adaptability in time and space?

In that issue of OASE, the work of architects Anne Lacaton and JeanPhilippe Vassal is mentioned. The author, after the presentation of three projects, concludes: "At this point only, the building might become a support for forms of collective inhabitation that are not merely left undetermined but remain genuinely unforeseeable." 5 This indication points to the concerns that are the subject of this article. Moreover, it should be noted that French architects refer to the theoretical ground that the 1960s ${ }^{6}$ represented to support their approach. But is this enough to claim the production of a model that, beyond its theoretical viability, can claim largescale replication?

In this article, we propose to follow the theoretical developments of the 1950s and 1960s that introduced the question of indeterminacy, adaptability and evolution into architectural theory, taking into account, in particular, the subject of the occupant in his personal and cultural singularities. We draw from these two key concepts that seem to us to be a possible synthesis of these theoretical developments.

We will then analyze, in the light of this theoretical framework, the work of two contemporary architects who have taken these questions into account in their concrete achievements and claim to produce evolving housing models: Lacaton \& Vassal, based in France, and Elemental, based in Chile. Their productions are less utopian, more pragmatic than those of the Team $X$ generation. We will assess whether this pragmatism allows their proposals, beyond responding to specific situations, to claim the status of a reproducible model.

\section{THEORETICAL CONTEXT}

\section{The "Aesthetic of Change": Issues of Evolution of the Architectural Form}

In the 1950s, some architects began to question the building model defined by composition principles stable over time and instead searched for formal principles involving possibilities of evolution, growth, and flexibility. These preoccupations were initiated by two groups: Constructionists and Independent Group, both based in London. ${ }^{7}$ These two groups had in common the identification of the notion of indetermination in architecture.

In 1951, in London, the Institute of Contemporary Arts and Independent Group presented an exhibition entitled Growth and Form. The title of the exhibition deliberately echoed the book on growth and form, by the biologist D'Arcy Wentworth Thompson which was published in $1917^{8}$ and the exhibition referred to drawings from Thompson's work, presenting patterns of biological growth. These patterns were interpreted as possible formal models including possibilities of evolution over time without changing nature. 
In 1956 the CIAM X in Dubrovnik was organized, where the theme of evolutive and adaptable architecture was one of the main topics debated. The framework ${ }^{9}$ was written by Alison and Peter Smithson, members of Independent Group. In this text, they particularly highlight the concept of "change" in architecture. The introduction of these subjects as major preoccupations represented a break with concepts of architecture that were based on the artwork as a finality. This sequence initiated the development of theories of change in the modern movement.

In 1957, another member of Independent Group, James Stirling, published an essay in the Architects' Year Book no. 8, where he stipulates:

The application of orthogonal proportion and the obvious use of basic geometrical elements appears to be diminishing, and instead something of the variability found in nature is attempted. "Dynamic cellularism" is an architecture comprising several elements, repetitive or varied. The assemblage of units is more in terms of growth and change than of mere addition, more akin to patterns of crystal formations or biological divisions than to the static rigidity of the structural grid. ${ }^{10}$

This statement illustrates the quest for an architecture that is no longer generated by a system of simple proportions and geometries, but by more flexible processes, inspired by cellular and molecular systems of organization.

This publication also contains an article by Peter and Alison Smithson: "The Aesthetics of Change." ${ }^{11}$ In this article, drawing on the case of the university, the Smithsons tell us that the university and the city are growing and changing.

Consequently, the new buildings of a university should no longer be conceived according to traditional aesthetic theory in which the part and the whole are in a finite relationship with each other, the aesthetic of each being "close." Their aesthetic must be an "aesthetic of change." Retrospectively presenting their Sheffield project, completed four years earlier, the Smithsons described the system of footbridges connecting the old building with the new as a "linkage" between independent elements, an elevated street. The façade, in addition, is made up entirely of screens, allowing all the class changes inside but without changing the external aspect.

In their article, the Smithsons also presented the Santa Monica house, designed and built by Charles Eames. For the Smithsons, this project was the expression of a "transient aesthetic," ${ }^{12}$ composed of elements that could be easily replaced over time and therefore expressing an "aesthetic of change."

\section{The "New Brutalism": Premises of a Shared Aesthetic}

Already at the time of its conception, brutalism was generally reduced to being an apologia for the use of raw material. However, as Reyner Banham had already pointed at the time,$^{13}$ its definition by the Smithsons more broadly 
covered the issue of social ethics, some of which echoing with the subject of the present article. Banham's book The New Brutalism: Ethic or Aesthetic? (1966) offers a valuable insight into the initial doctrine of this movement. Hunstanton's secondary school, created by the Smithsons in 1954, was interpreted by critics and by the Smithsons themselves as the first expressly brutalist building. It, therefore, appears to be a concrete manifesto of this doctrine. The architecture of the the building is characterized on the one hand by the absence of finishings, revealing the the nakedness of the structure, the means by which the materials were assembled and even the technical networks, and on the other hand, by a formal simplicity of spaces allowing for a direct understanding of the organization of the building (and also, presumably, greater ease of construction). As Banham reports: "No mystery, no romanticism, no obscurities about function or 'circulation'." ${ }^{14}$ All these dispositions lead to a pragmatism gathering construction economics and a claimed anti-sophisticated aesthetic.

Philip Johnson, who wrote a technically thorough article on this building, deplored what he interpreted as stylistic mistakes (referring to an "attempt to do Mies on the cheap" ${ }^{15}$ and, later on, describing a significant detail as "Definitely not elegant!" ${ }^{16}$ ).

The conclusion to this article rightly indicates that the Smithsons "have turned against such formalistic and 'composed' designs toward an Adolf Loos type of Anti-Design which they call the 'New Brutalism'." ${ }^{17}$ Further on, Johnson reveals what he thinks of this new doctrine, indicating that this title, New Brutalism, "is already picked up by the Smithsons contemporaries to defend atrocities." ${ }^{18}$ This reaction indicates, in a negative way, how the New Brutalism appeared at that time as a questioning of the internal codes of the discipline of architecture and, especially, of the importance of style and composition.

In the January 1955 issue of Architectural Design, the Smithsons set out their first explanation of the brutalist aesthetic with the following conclusion, "What is new about the New Brutalism among movements is that it finds its closest affinities not in past architectural styles, but in peasant dwelling forms. It has nothing to do with craft; we see architecture as the direct result of a way of life." ${ }^{19}$ We can analyze this reference to the peasant dwelling in terms of two aspects which respond to each other: on one hand, the wish to involve architecture in pragmatic ethics, based on the economy of means in the act of construction, and on the other hand the wish, by abandoning disciplinary elegance, to reveal the expression of anthropological components whose authenticity would bring more meaning to architecture. Further on in this issue, the Smithsons concluded their commentary on a low-cost social housing project constructed in Morocco by the architect Vladimir Bodiancky, with this statement:

It is impossible for each man to construct its own home. It is for the architect to make it possible for the man to make the flat his house, 
the maisonnette his habitat... We aim to provide a framework in which man can again be master of its house. In Morocco they have made it a principle of "habitat" that each man shall be at liberty to adapt for himself. ${ }^{20}$

The brutalist approach such as defined by the Smithsons, therefore, involves placing the architect in a position of withdrawal, keeping himself from any sophistication in the design of the overall structure, and abandoning responsibility for the aesthetic result, on one hand to the materials in their natural state and on the other hand to the users in the part left to them to appropriate the built space and finalize the building.

These concerns are reflected in two other later articles published as a series of texts under the title "Collective Design" and written by the Smithsons: "Initiators and Successors and Lightness of Touch." The first text echoes the qualities detected in Moroccan housing, on its ability to be appropriated. For Peter Smithson, this quality, which an architect can take into consideration in his design process, is the simplest level of a Collective Design:

For the architect, his contribution to collective design at its simplest should mean that when only a single building is to be added to an existing group, its space should lock onto existing ways and geometries and be itself "dressable" - that is, anticipating the occupiers' and future occupiers' design activities. ${ }^{21}$

Later in this article, describing their Robin Hood Garden project, based on a 1972 project description, he insists on highlighting the urban qualities of the street, as a space of connections and appropriation, as a qualitative extension of housing itself. For him, the dwellings are stated as enclosures but the exact internal use left open to interpretation to reflect the interchangeable use of rooms that ordinary dwellings require. ${ }^{22}$ In the second article, again using peasant housing, Peter Smithson tells us:

When we say that "lightness of touch" can allow a building to be interpretable we mean capable of being read in different ways by the occupiers so it becomes theirs without itself being changed, and when we say it should permit a building to be "dressable" we mean capable of responding to occupiers or community seasonal or festival decorations, or to temporary changes, without the underlying structures or meanings being destroyed - these structures and meanings being enhanced by such "dressing" (this is in fact the oldest and commonest of ideas, common to the temples of Greece, the shrines of Japan, and the Christian churches; and also common to old peasant and burgher houses almost everywhere). ${ }^{23}$ 
Defined in this manner, it paves the way for the ambitions developed by the Hansen's conference at the Otterlo congress and illustrates the definition of an "open aesthetic" such as described hereafter.

\section{The Hansen's "Open Form”: The Emergence of Singularities}

In 1959, during the Otterlo congress of the CIAM, a couple of Polish architects, Oskar and Zofia Hansen, gave a lecture entitled "The Open Form in Architecture - The Art of The Great Number." ${ }^{24}$ This lecture aimed at suggesting theoretical alternatives to modernist thought on the question of large scale.

First, Hansen introduced his conference by an open criticism of the lacks of architectural norms which had been practiced before. He denounced the inability of "closed architecture" to adapt to the "changes imposed by life." 25 For Hansen, Josef Hoffmann resolved, with the completion of the Palais Stoclet in Brussels in 1904, the problem of the "closed form." ${ }^{26}$ According to him, this project presents a situation where the "superspecialist architect" resolves the problem of the small quantity which "determines the order of everything - from the urban scale to the door knob." This solution cannot, for the lecturers, address the question of the large scale.

The quality of the "open form" takes into account the initiative of the resident, considering him as an actor in the formation of his environment.

The completely new task of the architect: a communicative transmission to our psychology of the organic and bountiful chaos of events in a form received by this manner [...] The manifestation of the Open Form will be therefore the discernibleness of the individual in the multiple, and the discernibleness of the number [...] The Open Form differs from the Closed Form by recognizing concrete people-not the abstract so-called "average"-by leaving a margin for evoking one's own latent essence. ${ }^{27}$

Architecture should therefore serve as a support to these unpredictable events and as an object which allows the process of appropriation. This embodies the notion of change, initiated at the Dubrovnik CIAM X (1956), and developed in the different articles by the Smithsons. The reference to the multitude is also highly significant of a change in the line of thought in relation to the modernist credo putting forward models applicable to the masses. If we consider the later definition given by Negri and Hardt, the multitude is "an open and expansive network in which all the differences can be freely expressed and, at the same time, allows us to live and work together." ${ }^{28}$ The multitude differs from the mass in the way it implies simultaneously the great number and its diversity. We can see to what extent the Hansens sought to integrate, while thinking about globality, the emergence of the individual in his singularity. 
The Indeterminate Building: Growth and Adaptation

The "aesthetic of change" approach initiated by the Smithsons would be further developed in the project for the Northwick Park Hospital, designed by John Weeks of the Llewely Davies and Weeks firm of architects, and also a member of Independent Group.

Before coming to this project, we should recall that Richard Llewelyn Davies, an associate of John Weeks, gave a conference to the Architectural Association in 1951 on the topic of "Endless Architecture." 29 Integrating other disciplines distinct of architecture, Davies referred to the writing of James Joyce as "endless writing," as some of his works have no beginning, middle or end.

These considerations on endless architecture were followed by the architects in the aforementioned project. The authors developed a strategy of indetermination, in order to construct a project subject to unpredictable modifications, integrating growth dimensions and changes due to the obsolescence of hospital departments. In order to be conceptually "endless," Weeks indicated that the size of the hospital project was not determined because the "growth of the different departments would be typically unequal and difficult to predict." 30

The team of project authors, therefore, suggested a "street" on which several departments of the hospital interconnect. Only the widths of the volumes are defined, their lengths remaining undetermined. The departments are therefore free to develop independently of each other. The interior of the buildings can, thanks to their structural system, be subdivided, in a way that is not connected with the expression of the outer envelope, following the suggestion by the Smithsons for Sheffield, and concretizing an "aesthetic of change" and a system of "linkage," ${ }^{31}$ the backbone of the project.

Regarding this project, it is interesting to note that Weeks added that the shape of the entire building should not be closed, or "finished": "The ideal of unity with constant relationships cannot be attained," said Weeks. Such a building must be geometrically "a-formal." 32

\section{From Massification to Fragmentation: A Shift Towards a Post-Universal Context}

If the theoretical developments operated in Dubrovnik and Otterlo had the objective of a deep critical redefinition of modernist theories, they shared with it the ambition of a radical and global transformation of living conditions, without any limits of scale through time and space.

At the beginning of the 1970s, in the context of deep questioning of these global models, the Smithson wrote a series of articles in which they reconsidered the notion of the collective and suggested a change of point of view. Starting from an architectural theory based on massification (the greater number), they suggested reorienting towards a fragmentation, 
offering more individual freedom, an "increased model of diversity." 33 The most striking article indicating this reorientation was published in "The Violent Consumer, or Waiting for the Goodies," written in 1974 after abandonment of the collective housing project of Robin Hood Gardens:

The idea of fragmenting the mass movements, compartmenting in free choice, is worth trying [...] Fragmentation, so that the pieces each become the size that mends minds, responding to those demands in society that are poles apart at the moment: the wish for anonymity - or identity; the desire for patterns of association or disassociation; a turn away from the solution to be universally consumed towards solutions personally made or chosen; a return to different quality of life to be enjoyed in built places... We must move on to that next level where the underlying belief in brotherhood is rooted in a sufficiently strong trust that we are all Greeks [...] to allow society to freely fragment, become compartmented, group in its own loose way, seek difference in quality through effort in workor not, as the case may be. ${ }^{34}$

The question of the multiplicity of singularities was already present in the conference on the open form by the Hansens. However, here it reaches a supplementary degree of impregnation. It is no longer a case of only considering the individual, but also groups at all scales ("fragmenting the mass movements," "patterns of association") these being left to their free association, not determined by patterns or preestablished structures. In 1978, Rem Koolhaas published Delirious New York. ${ }^{35}$ He described there the town as an "archipelago" as "cities within cities." The more each island celebrates different values, different identities, the more the unity of the archipelago as a system is reinforced. In this model, "change" is contained in the components of the islands, which freely develop in relation to each other while also interacting with each other. These considerations on fragmentation appeared barely three years after the article by Alison Smithson and initiated the idea of the town in the town, later developed in the work of OMA.

\section{DEFINITIONS}

At this stage, we wish to synthesize these theoretical contributions by distinguishing two key concepts both of which are linked to the understanding of architecture as a dynamic and evolutionary process.

\section{The "Open Structure"}

The "open structure" results from an application of the principles of "growing form" and "aesthetic of change" as previously described. It represents a way of understanding architecture not as a finished object, but as a perennial support enabling temporary appropriations that are sustainable 
to a greater or lesser degree. The concept of an "open structure" also presupposes a capacity for growth and transformation in time, without change of nature. Following the biological and molecular structures put forward by Independent Group in the exhibition Growth and Form, it is organized around principles of spatial arrangements, "patterns," offering supports and facilities for the implementation of functional programmes that are partially or totally indeterminate.

This principle supposes a possibility for the evolution of architecture over time, considering that the programmes which take place in the structure as defined can be added, withdrawn or modified without changing it. The structure, whether or not it is seen as perennial, possesses greater sustainability than the programmes it welcomes.

An architecture incorporating the "open structure" principle can also be designed in such a way as to expand over time, extending the principles of arrangement from which it was organized in the first place, like the "endless architecture" theorized by Llewelyn Davies and Weeks, and whose principles are applied to the Northwick Park Hospital project.

Applying the "open structure" principles involves defining the minimal spatial characteristics necessary for the viability and quality of an architecture intended to develop over time and/or to receive variable programmes over time.

In addition to the theoretical origins mentioned above, this principle of the "open structure" was largely applied in the neo-avant-garde projects developed during the 1960s by the members of Team X, their successors, and, in its more recent developments, in architectures defined as a "milieu" or as an "internal landscape" by some contemporary Japanese architects. ${ }^{36}$

\section{The "Open Aesthetic"}

The "open aesthetic" is heir to the brutalist considerations of the Smithsons, extended and completed by the "open form" of the Hansens mentioned above. It consists of imagining the purpose of architecture not as the incarnation of a drawing totally mastered by the architect and resulting in a physical object offered to contemplation, but as the result of an evolutive process partially escaping the determination by the architect.

In a 1959 text published in the journal Le Carré Bleu, the architect John Voelcker cited the work of Solton \& Hanson presented at the Otterlo CIAM congress as an "open aesthetic," and defined it in these terms:

To consider form as a master key likely to serve as an instrument to satisfy the many solicitations of life [...] it is the diversity of individuals and their actions which form the primary element of this open aesthetic and its architecture aims to play the role of a mobile art whose object is formed by the events themselves. ${ }^{37}$ 
The open aesthetic, therefore, anticipates the future uses from the project design and proposes to suggest, encourage and even provoke them. It involves that the architect abandons part of his control on the final result, and conceives architecture rather as a support capable of receiving multiple aesthetic scenarios, mostly conceived by the user, or the succession of users.

In this perspective, the aesthetic outcome of architecture will incorporate not only its material and construction component, but also, as was described by the Hansens, a dynamic component, an "art of events," whose effects will, by definition, be variable over time.

We also wish to suggest another possible component for the open aesthetic which completes the previous one and rejoins it under certain aspects. It consists of the own discourse of raw construction.

Firstly, it is important to distinguish the notion of raw construction from the simple use of raw materials left exposed. Certain architectural strategies using raw materials, like the approaches of Mies van der Rohe, Louis Kahn or, more recently, Peter Zumthor, show a clear intention to manage all the formal arrangements of materials, even when these are left in their raw state. This intention is expressed in the implementation of construction processes that are often sophisticated, in an objective of maximum control over the final result. These strategies are part of a "closed" aesthetic, where the object predominates and where the control of the architect over its integral (or aims to be).

On the other hand, the use of raw material in certain projects by Le Corbusier, the Smithsons, or Lacaton \& Vassal, which we will see later, shows a will to laisser faire the material and its arrangements (what Le Corbusier called "le romantisme du mal foutu" ${ }^{38}$ ). In contrast to an approach seeking to master all the visual effects generated by the arrangement of materials, this posture promotes the use of materials and construction techniques devoid of sophistication, seeking to approach and make visible the act of construction in its basic truth. This posture echoes the brutalism of the Smithsons. When they evoke their interest in "peasant dwelling forms" in place of "past architectural styles," 39 they are highlighting their interest in an architecture emerging from the expression of the direct contingencies of its realisation: economy of means, techniques of simple construction, attached to a specific time and place, and which do not seek to conceal their nature. Hunstanton's school project illustrates this approach.

To paraphrase Adolf Loos, already cited above by Johnson as an activist of Anti- Design, this strategy could be well illustrated in the credo "finishing is a crime." It induces that the architectural result aims to make legible the dynamic processes that made it exist.

We suggest incorporating these considerations on raw construction into a definition of the open aesthetic for two reasons: firstly, in the case of the Smithsons, they are contingent to the developments about the open 
form, even if this proximity is not explained by them. Then, they are, in our opinion, part of the same ethical principle which consists of the architect abandoning part of his mastery on the object to voluntarily reveal, or allow to exist, dynamics which he is not involved in but that he aims to highlight. To caricaturise, the architect no longer acts here as creator but as the conscious revealer of realities that are beyond his control. We will see immediately afterwards that this approach finds a particularly relevant echo in the posture of architects Lacaton \& Vassal.

\section{CONTEMPORARY SYNTHESES}

\section{Lacaton \& Vassal: Extra Space and the Aesthetic of "As-Found"}

\section{Extra Space and "Open Structure"}

On their return from Africa, Anne Lacaton and Jean-Philippe Vassal worked on the project of the Latapie house. For these architects, it was important to think of housing in an alternative way. This project was an occasion for them to think about the type of housing an ordinary family could afford. This reflection leads to an estimated surface area of $80 \mathrm{~m}^{2}$ [861 sq. ft.] for the housing if it were built under conventional conditions. The objective followed by the architects was to produce a bigger house, "not an extra $10 \mathrm{~m}^{2}$ [108 sq. ft], but perhaps twice as big if possible, because we are intimately convinced that you would live better in a big house and that also offers an opportunity to have different sorts of spaces and atmospheres." 40 The architects responded to this equation by designing the accommodation inside an agricultural greenhouse, an industrial device making it possible to provide an inner space with a controlled climate and with very low construction costs.

This "extra space" is also mentioned by the architects as "double space" 41 depending on the project. This quest for a complementary space aims to offer increased quality of life to the inhabitants, and freedom of appropriation due to the fact that the available space is not totally invested by a determined program. For the authors of the project,

You do not have to conceive everything; you just have to give [the inhabitant] the potential space to be used and appropriated. If you give enough qualities and a range of capacity, then you provide maximum opportunities for everybody and the project will assume to be changed, transformed and re-appropriated. ${ }^{42}$

For Lacaton and Vassal, this possible degree of appropriation and freedom is a definition of "luxury": "luxury" is linked to freedom of use and a high level of possibility and minor constraints, in order not to set limits to your imagination and desires and is not linked to the cost ${ }^{43}$ of a construction. By the way, the architects humorously adopted a famous advertising slogan from a car brand, "What if real luxury was space." 44 
In a text published in $2014,{ }^{45}$ the architects claimed principles that were very close to the definition of the open structure mentioned above. Besides, the term "open structure" is cited in this text:

We always aim to make [the structure] independent of what it contains, so as to let this content emerge. The structure should be free, very roomy, in order to create a new rapport with climate and the ambiance, a new rapport with activity so as to produce the conditions for mobility and enjoyment. A structure that generates urbanism through its capacity to interfere with existing structures and activate the urge to continue the city. We always approach this concept of an open structure through the imaginary aspect of the fabric, the imaginary aspect of the expanse [... ${ }^{46}$

In this short extract we find the two general principles of the open structure: programmatic indetermination ("the structure independent of what it contains") and the possibility of growth ("activate the urge to continue the city," "imaginary aspect of the expanse").

Later, Lacaton \& Vassal spoke about the possibilities offered by the use of agricultural greenhouses as a basic structure for creating housing or other programmes, as "an open structure for inventing climate and ambiance." 47 They indicate that, contrary to the usual "defensive" ${ }^{48}$ approaches concerning the insulation of buildings, agricultural greenhouses are envelopes that "play and react with the outside." ${ }^{49}$

\section{The Aesthetic of "As Found" and "Open Aesthetic"}

If it reveals partly, as we have seen, the heir to a certain spirit of brutalism, the approach of Lacaton \& Vassal takes place in an era when the conditions of realization of architecture changed profoundly. Firstly, industrial prefabrication and the systematisation of construction methods have strongly progressed, touching all scales and all programmes including individual housing. Following this, normative frameworks in the areas of safety, sustainability, energy and technical performance have greatly increased the standards of minimal quality concerning architecture, at least in the developed countries, increasing the building costs.

We have seen above how Lacaton \& Vassal suggested to significantly increase the housing by offering an extra space. This extra space, created within the budgetary limitations of a standard project, is rendered possible by using poor materials and industrial devices (agricultural greenhouses) diverted from their primary use. The architects, therefore, assume, for this extra space, to work with very low finishing standards, in order to offer this extra space which is considered, as we have seen above, as the source of a certain idea of luxury. In view of the post-2008 economic context, this "as found" design could constitute a benchmark for building qualitative housings for the greatest number of people, and thus provide a framework 
for the role that the architect can play in defining architecture. This is in line with Smithson's concerns about the architects' provision of a "dressable" building for its occupants and could answer a contemporary economic issue in building affordable dwellings.

This philosophy relates to the principle of "anti-design" raised by the brutalists, with the difference that here, it is no longer the raw materials which constitute the envelope of the housing, but a prefabricated object deviated from its use, an architectural translation of Duchamp's "readymade." By orienting the validation of an architecture on the space it makes available to appropriation rather than the sophistication of finishings, the architects support an anti-elitist vision of housing, while at the same time offering the user an extra potential to enrich its mode of living and uses within his housing.

These considerations are in line with the principles of the "open aesthetic" as defined above. The final aesthetic result shown by this approach is the opposite of the expression of a fixed design. As the polycarbonate generally used to realize this extra space is a generic industrial material, the final image which results from its appropriation is strongly influenced by the elements of customization introduced by the user.

Beyond the image, the use of the extra space itself is the object of a strong definition by the resident, without a specific predisposition caused by architecture. This result would undoubtedly not have been disowned by the brutalists, who spoke of supplying "a framework in which man can again be master of his house." ${ }^{50}$ Karine Dana speaks about the addition of the script of the user to that of the architect. ${ }^{51}$ Rather than addition, Lacaton and Vassal suggest a "superimposition," 52 and they extend this principle to all their conceptual approach, from the way the site is considered to the place left to the user in the definition of the final result.

The site is, therefore, never considered as a negative situation to be resolved or repaired, but as a pre-existing tissue to be preserved, on which the goal is to "superimpose [their] new intentions, but without imposing them onto pre-existing systems." ${ }^{53}$ The logic of the "as found" is therefore equally valid in the way the site is considered. This way of acting as revealers of an existing reality without transforming it is also in line with the definition given above of the "open aesthetic."

This preoccupation with the "existing" is also in line with the considerations of the Smithson's concept of "as found."

In 1990, continuing their reflections on the notion of context, the Smithsons revisited their previous considerations of the "as found." They reformulate the concept as follows: "In the early 1950s, we wanted to rethink architecture, we meant by "as found" not only the adjacent buildings but all those traces that constitute the memories of a place and that must be read to discover how the built and existing fabric of the places came to be." ${ }^{54}$ In this review, the context is defined by the integration of a new element into 
an existing one as found, but also by way of thinking about the collective, whose elements are already present in the text Reassessment of concepts in urban planning:

The concepts by which we give form to the collective seem to need to be reassessed. They probably belong to the individual perspective of the moment. Yet we can well understand that the preservation of four hundred old trees in a housing estate not far from a suburban train line - and where we are soon (fifty years later!) going to rebuild small houses - will offer a wonderful setting, which will allow new to enjoy new, will serve as a bridge, a significant link between new and "as found." 55

\section{Lacaton \& Vassal: The Cité Manifeste Social Housing Project in Mulhouse}

The Cité Manifeste housing project in Mulhouse, completed in 2005, presents a continuity of the investigations into the extra-space initiated with the Latapie and Coutras houses. The considerations on the necessity to offer extra space for the appropriation of the users, offering them a certain vision of luxury, was extrapolated here in order to be applied to collective buildings.

The architects wanted to abandon the classic gesture which consists of managing "the minimum where one makes every effort to gain half a square meter here and there." ${ }^{56}$ To escape from this, they opted for a loft-type system, "namely an envelope that's as big as possible." ${ }^{57}$ The goal was to allow the residents to make the most of the qualities of this open structure.

On the ground floor, the architects drew a regular concrete structure, a grid of $7,5 \mathrm{~m}$ by $6,5 \mathrm{~m}$ [24.6 by $21.3 \mathrm{ft}$.], which acquired a value in allowing for the appropriation of the ground, while at the same time aiming not to distort the original situation of the place. This concrete frame was designed to withstand urban constraints, offering the possibility of detaching the greenhouse from an anchorage on the ground floor which was considered too vulnerable. The greenhouse was taken as it is, without modifying any of the constituent elements of it, in order to maintain the performance/cost ratio of this structure (Fig. 1).

Once the grid was fixed to the ground and the greenhouses placed on top of it, the architects partitioned it into eleven irregular parts. As the primary structural grid offered an open plan, the partitions were completed independently of it in order to obtain living spaces with a maximum width of 5 to $7 \mathrm{~m}$ [ 16 to $23 \mathrm{ft}$.]. To do this, the walls separating the housing units leaned forward in places to offer the maximum width criterion that the authors had set. This situation offered a diversity of dwellings where one could distinguish living spaces both at first floor and ground floor. This also highlighted the total freedom of the concrete frame in grid form of which the facade is independent. Conversely, the structure of greenhouses is more restrictive and gives a better definition to the façade and partitions. 
The appearance of the building could be that of a "transient aesthetic" in the sense that the Smithsons understood it when speaking of the Eames house in Santa Monica. The polycarbonate elements of the greenhouses, with the garage doors filling the spaces between the concrete columns, seem to be able at any time to be modified, reversed or changed. Upstairs, the greenhouses are partially insulated and heated. The non-insulated part represents the "extra space," a winter garden that can be appropriated. The heated part was also provided with a solar protection system to regulate the interior atmosphere of the dwellings.

The aesthetic result is, as the architects explicitly claim, part of the brutalists' legacy of thought. The great attention paid to the adaptability of housing, the appropriation capacities delivered by extra space, and the aesthetics exposing constructive principles, undoubtedly constitute components of the brutalist doctrine as expressed by the Smithsons.

However, the result seems to suffer, like the achievements of its predecessors in the 1960s, from a difficulty in displaying itself as a model that can be applied on a large scale. Indeed, far from revealing a neutral aesthetic, which would allow the inhabitant to "customize" his home by giving it its own style, the architecture of Lacaton \& Vassal is very stylistically assertive, affirming its raw materials and its bare joints. Aesthetic neutrality here seems to contradict the logic of "as found," which leads to a very assertive style that is difficult to hide unless it explicitly contradicts the architectural logic of the project. Only users who benefit from the cultural codes that allow them to give meaning to this particular aesthetic are therefore destined to appropriate these dwellings.

At the Nantes School of Architecture, as in many other projects, Lacaton \& Vassal also implemented the logic of "extra space." An article written by Valery Didelon, who taught in this school and experimented this buildings, explains how little these spaces are exploited, and at times become elements of constraint rather than freedom. As they are programmatically indeterminate, they require a lot of effort to be made practicable for certain specific uses (work or exhibition equipment, lighting, technology). The result is that these spaces are rarely used, and also entail additional costs (heating, security) which relativize their economic and practical interest.

At the end of this analysis, "extra space" appears to be an architectural device that finds its relevance in certain specific applications, but that its inventors themselves have too quickly tended to present as a systematic solution. In some situations, managing this "extra space" brings more constraints than freedom. As for the aesthetics of the "as found," it cannot claim the neutrality that would be necessary for the free expression of the inhabitant's desires.

Like brutalist proposals, it is therefore difficult to consider Lacaton \& Vassal's proposals as embodiments of a theoretical model that can be applied on a large scale. 


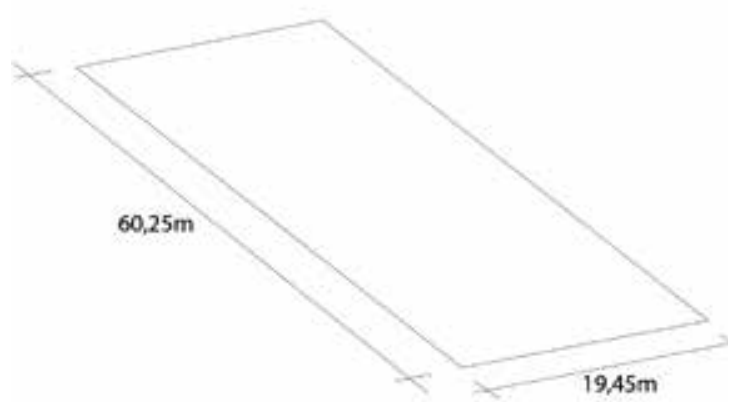

(a)

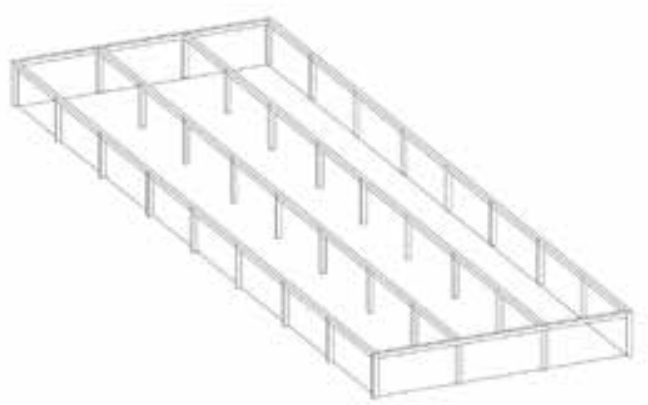

(b)

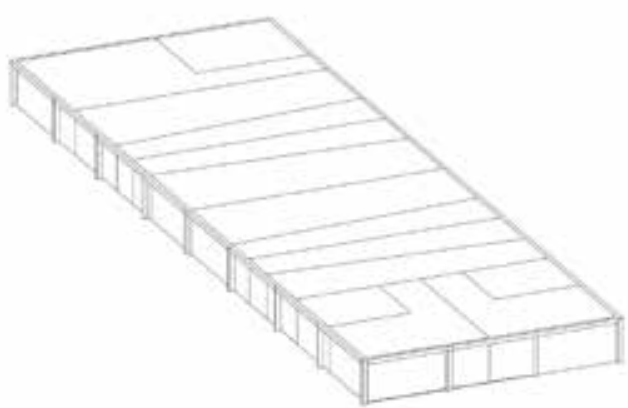

(c)

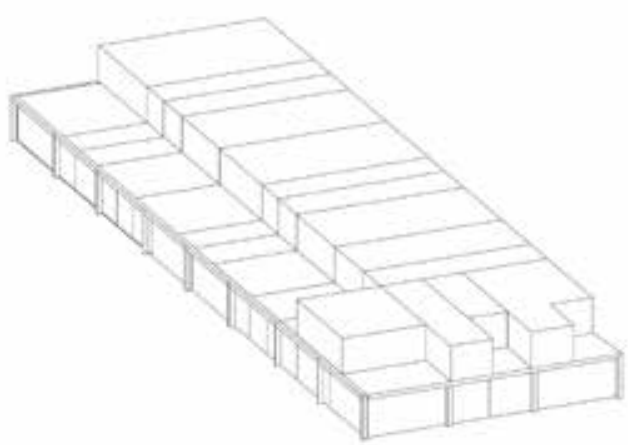

(d)

Figure 1. (a) Plot size;

(b) concrete structural grid

7,5x6,5 m [24.6x21.3 ft.];

(c) groundfloor subdivision;

(d) interior heated volume;

(e) extra-space contained

in greenhouses.

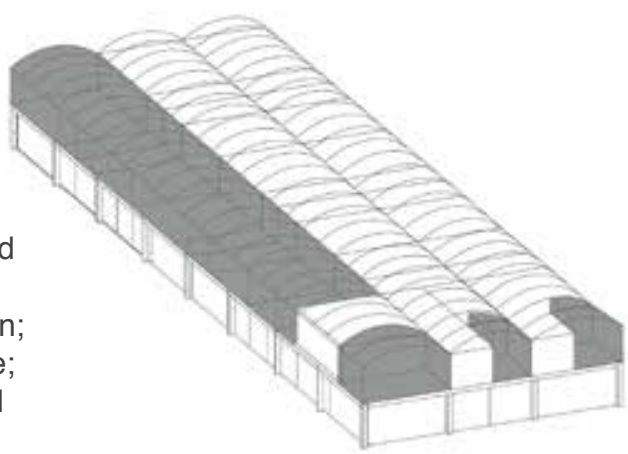

(e) 


\section{Elemental: Half Space and Self-Construction}

Another example calling on the double strategy of structural and aesthetic openness is the approach taken by the agency Elemental, based in Santiago in Chile, on the question of social housing.

\section{Half Space and "Open Structure"}

Elemental developed a strategy for several housing projects in Chile which consisted in building half a house, the other half being left free in the urban tissue to allow a future extension by the resident in accordance with his needs. This strategy is named "incremental housing" due to the fact that each housing has, without disturbing the overall urban planning, the possibility for an extension of up to twice the initial surface.

By allowing this possibility of further development in a space left empty, this arrangement stabilizes a planned urban surface which would otherwise be subjected to anarchic interventions over time, "with a strong possibility of being chaotic." ${ }^{58}$ This principle of "incremental housing," as it proposes an architecture that is somehow unfinished, is a possible illustration of the "open structure": its architecture is displayed as a support to later developments, whose formalization has not been preestablished but uniquely suggested by a basic planning.

However, as in the case of Lacaton \& Vassal, the assimilation of this aesthetic principle with an "open form" as theorized in the 1950s cannot be complete, because here we cannot speak of "endless architecture." The condition of the fragment keeps here its relevance on all levels: if the expansion of the form is possible, it is only so in a perspective limited to doubling the initial space. In addition, this extension can only be completed in a preestablished space so that the size of the building becomes progressively unified and ends by constituting a general form that is almost "closed."

\section{Self-Construction and "Open Aesthetic"}

The conclusions are similar if we observe this approach from the angle of the "open aesthetic" as defined above. Alejandro Aravena, on this subject, speaks of "considering the historical criticism of social housing: its inability to respond to the diversity of conformations, tastes, and sensibilities of different families." 59

The basic building supplied by the architect is basically a $30 \mathrm{~m}^{2}$ [323 sq. ft.] minimal housing, equipped with all the sanitary and technical equipment, and arranged according to a repetitive serial pattern, established exclusively according to the economy of means. Aravena feels responsible for this bareness but says that the self-construction proposed to the inhabitants will allow each housing unit to adapt to the needs of the inhabitants and that the self-built parts will break the monotony of the initial structure. 
Here also we find the principles of form as a "framework in which man can again be master of his house" (Smithsons), and concerning the overall result, "the open form [that] manifests itself by the presence of the individual in the multitude as well as by the intelligibility of the number" (Hansen). In this respect, Elemental's approach meets the challenges of "open aesthetics" as we have described before, at least in principle.

Anyway, this preoccupation activates and puts into perspective the possibility of a building to be "dressable" and self-construction seems to be a possible response to economic issues in the design process.

\section{Elemental: Quinta Monroy in Iquique}

The Quinta Monroy housing project in Iquique in Chile, developed by the Elemental agency, takes place in a site close to the city center, illegally occupied by around one hundred families. The project involves home ownership by these families using a governmental subsidy of US $\$ 7,500$. This budget allows, in the context of local construction criteria, to build a surface of around $30 \mathrm{~m}^{2}$. The rest of the budget to complete the housing must be supplied by the residents.

Rather than constructing complete housing units, the participative process established with the inhabitants of the site led to the implementation by the architects of the principle of "incremental housing" described above. This involves the construction of a basic setting composed of a minimum housing core with an equivalent intermediary space for extension (Fig. 2). Analysis of the plan makes it possible to conclude that these basic housing units are very small to accommodate a family (a single room and a $3 \times 4 \mathrm{~m}$ [10x13 ft.] living room), even though they comply with the minimum housing standards in Chile. The extension of the housing in the area reserved for this purpose shows itself to be urgently or immediately necessary for most of the residents.

Thus, if the half-space principle established by Elemental is in line with the definition of an "open structure" as defined above, it is, however, necessary to express reservations about this, and these relate to the size and quality of the initial core. In the case of the "extra space" of Lacaton \& Vassal, this extra space made available is added to the basic structure, supplying a non-necessary surface open to creativity and the unpredictable. In the case of the Elemental housing units studied here, the basic core is minimal, so that the extension proves in most cases to be essential to the creation of normal accommodation. Even if the principle of variation and adaptation by the resident remains relevant here, the surface area available for extension remains quite limited. This extension must not be considered as a free space which is added to the basic requirements, but rather as a space available for just filling up these basic needs. This observation is not without consequences for the emancipatory dimension of the concept. 
This principle has been criticized in an article published in 2016 in Revista de Arquitectura. The authors, Camillo Boano and Francisco Vergara Perucich, denounce the emancipatory illusion of the strategy established by Elemental in these terms:

The problematic contradiction starts with the concept. First of all, the idea of offering "half house" to low-income communities seems somehow insulting because it implies that the finished project will depend on their individual (entrepreneurial) capacity to get the funds to build the other half. Where is the architect, and where is architecture in the other half of the house? What can be seen today, thirteen years after the completion of the Quinta Monroy project, are cheap construction techniques collated in what finally results as an expensive shelter. Adaptation, self-construction and community innovation are certainly central issues, but approaching them by leaving half of the house unbuilt can easily lead to the anesthetization of poverty and the subsequent processes of marginalization. ${ }^{60}$

A possible response to the criticism of Boano \& Perucich is that the solution of "incremental housing" in Quinta Monroy is the result of a decisionmaking process established with the residents, and that the construction of an entire housing unit would have resulted in an obligation to supply more funds at the start which was inaccessible to most of the future residents. The solution proposed by Elemental in Iquique could, therefore, be seen as a pragmatic response in a specific situation which, it should be remembered, takes place in a very different socio-economic context than western Europe.

However, the analysis of Boano \& Perucich weakens the ability of the halfspace to represent an emancipatory model applicable on a large scale. This analysis resonates with the vision of the Smithsons when they establish the responsibility of the architect in the definition of the "framework," 61 this responsibility being associated with a social ethic. The simple fact of leaving a free space for the extension of a housing unit does not seem, in this perspective, sufficient for leading to an overall quality which would sustainably resist the contingencies of further individual developments. Even if this question cannot be decided at this stage, it allows us to recall the attention that needs to be paid to the distinction between perennial elements and mobile elements, and the distribution of roles between the architect and the resident. Both have specific skills, and they cannot be substituted for each other. In an echo of the criticism of Boano \& Perucich, an article in Monde Diplomatique published in 2016 pointed out that "in 2013, nine years after its creation, the experimental quarter [of Quninta Monroy] showed damaged public spaces, unhealthy building, and was little different from the slums 


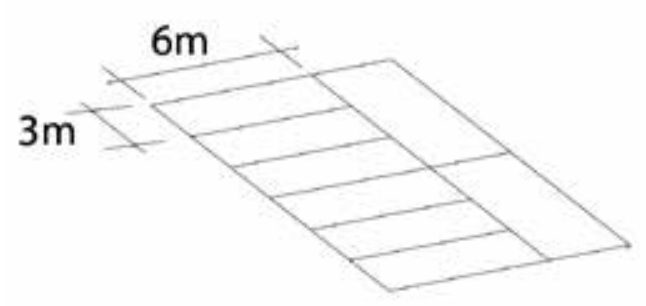

(a)

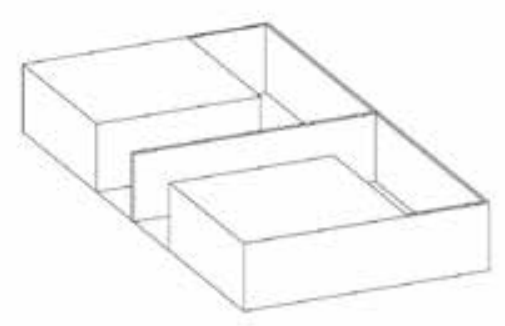

(b)

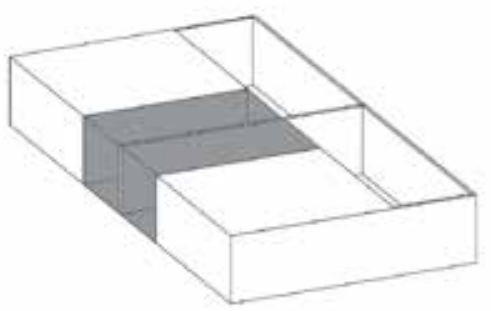

(c)

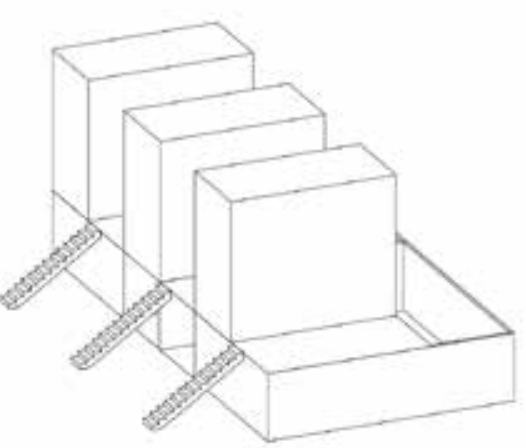

(d)

Figure 2. (a) Standard plot:

9x18 m [29.5x59 ft.];

(b) initial ground floor: two apartments with courtyards; (c) ground floors extension possibilities;

(d) initial upper floors: three duplexes;

(e) upper floors extension possibilities.

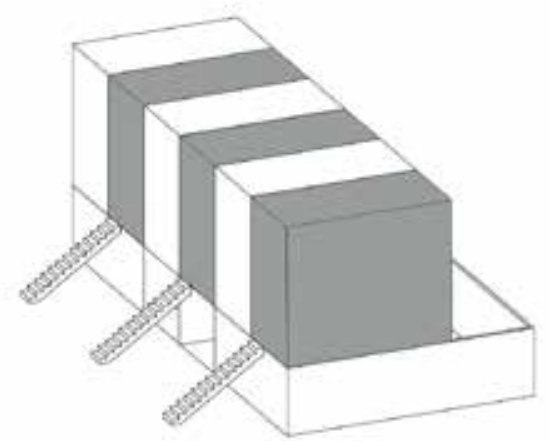

(e) 
it was supposed to replace." 62 This diagnosis conflicts with the argument of the architects who claimed the "aspiration to a design which enabled an urban area not to begin to deteriorate the day after the houses were supplied, but rather favored its validation over time." 63

\section{CONCLUSION}

We have seen that the 1950s and 1960s were rich in theoretical contributions on the issue of housing for a large number of people and its adaptability to changes in the context and its occupants. However, even if some specific achievements have emerged, the theories developed at that time did not result in a concrete application on a large scale.

While this lack of immediate effect on constructed reality does not invalidate these theoretical foundations, they do establish the relevance of the Smithsons' answers on the impossibility of applying an architectural model at the global level, referring to the notion of fragmented reality and the preeminence of situations. This observation made in the 1970s has not been questioned so far.

The two contemporary models we have studied are attempts to revive models in response to specific economic, political and social situations. These models, heirs or not conscious heirs of the radical theories of the 1960s, propose a pragmatic approach to their application, with the ambition of applying them to concrete and reproducible architectures. Both propose an evolutionary architecture, integrating uncertainty and leaving a significant part of the initiative to the user. While the difference in the contexts in which they are set prevents their direct comparison, it is possible to analyze the different ways in which they define the limits of what architecture can do.

Lacaton \& Vassal define all structural, spatial and climatic parameters. They intend to provide the occupant with an available space which, by its size, invites appropriation and increased life, "luxury," without elitist connotation. As Tom Vandeputte mentioned, the issue "testify to the awareness that the appropriation is not only limited by the walls that enclose it but also by the fixed patterns of inhabiting it." 64

Elemental designs basic equipment and an available template, and leaves a significant part of the structure to the occupant. It takes note of the latter's involvement in an informal economy which presupposes the possibility for him to build the remaining part with a strong economy of means, and in a temporality which belongs to him.

In both cases, the introduction of indeterminacy factors meant that the architect had to relinquish some control over the final result. In both cases, it attempts to offer a response to the precarious, unstable and uncertain nature of contemporary reality, by offering residents a measure of freedom to define and develop their own living environment, as the theoretical architects of the 1950s and 1960s had imagined. 
However, as Valery Didelon's articles on the work of Lacaton \& Vassal or Boano \& Perucich on Elemental's work suggest, it appears that the theoretical ambitions of these proposals do not necessarily materialize in the concrete reality of the buildings once they are made available to users. In this respect, and subject to further investigation, it seems that the difficulty encountered by architects in the 1960s in translating their theoretical models into concrete developments is also found in their contemporary heirs. This difficulty does not invalidate these steps in absolute terms, but limits their scope, and defines them only as possible answers, in certain specific situations.

A theoretical model that makes it possible to understand impermanence and singularities is therefore not to be found in the two architectures we have analyzed, despite the claims made by their respective approaches. However, don't the two key concepts of "open structure" and "open aesthetics" allow for other formal translations, which could meet these objectives? The answer to this question requires an extension of this research.

\section{Notes}

1. Many authors have touched on this subject, for an introduction to the British context see David Jeremiah, Architecture and Design for the Family in Britain (Manchester, UK: Manchester University Press, 2000), 1900-70.

2. In 1953, as a member of the GAMMA group at CIAM 9, George Candilis presented the project for the Central Quarries of Casablanca and spoke of "habitat for the great number" for the first time.

3. "Footprint 24: The Architecture of Housing after the Neoliberal Turn," Footprint, January 1, 2018, https://journals.open.tudelft.nl/index.php/footprint/announcement/view/44

4. Klaske Havik, Véronique Patteeuw and Hans Teerds, "Editorial, Productive Uncertainty/ Indeterminacy in Spatial Design, Planning and Management," OASE no. 85 (2011): 3-5.

5. Tom Vandeputte, "Economy and Excess/Three Recent Projects by Lacaton and Vassal," OASE no. 85 (2011): 110.

6. Cristina Diaz Moreno and Efren Garcia Grinda, "Everyday Delights. A Conversation with Anne Lacaton and Jean Philippe Vassal," El Croquis, no.177/178 (2015): 27.

7. For further developments, see Jonathan Hughes, "The Indeterminate Building," in NonPlan: Essays on Freedom, Participation and Change in Modern architecture and Urbanism, eds. Jonathan Hughes and Simon Sadler (Oxford, UK: Oxford Architectural Press, 2000), 90-103.

8. D'Arcy Wentworth Thompson, On Growth and Form, 2nd ed. (Cambridge, UK: Cambridge University Press, 1942); or. ed. (Cambridge, UK: Cambridge University Press, 1917).

9. Alison and Peter Smithson, "Draft Framework 4, 1956, Concept Document for CIAM X," in Team X 1953-1981, in Search of a Utopia of the Present, ed. Max Risselada and Dirk van den Heuvel (Rotterdam, The Neth.: NAI Publishers, 2005), 48-49.

10. James Stirling, "Regionalism and Modern Architecture," Architects' Year Book, vol. 8 (London: Elek Books, 1957): 62-68.

11. Alison and Peter Smithson, "The Aesthetics of Change," Architects' Year Book, vol. 8 (London: Elek Books, 1957): 14-22.

12. Ibid., 22.

13. Reyner Banham, The New Brutalism: Ethic or Aesthetic? (London: Reinhold Publishing Corporation, 1966), 47.

14. Ibid., 19.

15. Philip Johnson, "School at Hunstanton Norfolk," Architectural Review (1954), 148.

16. Ibid., 152.

17. Ibid.

18. Ibid. 
19. Reyner Banham, "The New Brutalism," Architectural Design (January 1955), 46.

20. Ibid., 47.

21. Peter Smithson, "Initiators and Successors," Architectural Design, no. 10 (1973), 621.

22. Ibid.

23. Peter Smithson, "Lightness of Touch," Architectural Design, no. 6, (1974), 378.

24. Oscar Hansen, "La forme ouverte dans l'architecture - l'art du grand nombre," Le Carré

Bleu, no. 1 (1961): 4-5.

25. Ibid., 4.

26. Ibid.

27. Ibid., 5.

28. Antonio Negri and Michael Hardt, Multitude: Guerre et démocratie à l'âge de l'Empire (Paris: La Découverte, 2004), 132.

29. Richard Llewelyn Davies, "Endless Architecture," Architectural Association Journal, no. 67 (1951): 106-113.

30. John Weeks, "Indeterminate Architecture," The Transactions of the Bartlett Society 2 (1963-1964): 83-106.

31. Alison and Peter Smithson, Ordariness and Light: Urban Theories 1952-1960 and Their Application in a Building Project 1963-1970 (Cambridge MA, USA: The MIT Press, 1970), 157. 32. Ibid., 90.

33. Dirk van den Heuvel, "Team Ten Diagrams," Daidalos, no. 74 (2000): 50.

34. Alison Smithson, "The Violent Consumer, or Waiting for the Goodies," Architectural Design, no. 5 (1974), 274-79.

35. Rem Koolhaas, New York Délire (Marseille, Fr.: Editions Parenthèses, 2002), 294 ; or. ed. Delirious New York (Oxford, UK: Oxford University Press, 1978).

36. See on this topic the developments of Jaques Lucan in Jaques Lucan, Précisions sur un état présent de l'architecture (Lausanne, Switz.: Presses polytechniques et universitaires romandes, 2015), 210-29.

37. John Voelcker, "D’Aix-en-Provence à Oterlo ou l'agonie et la mort du C.I.A.M.," Le Carré Bleu 41959 Feuille internationale d'architecture (Paris: Le Carré Bleu, 1959).

38. Le Corbusier, Entretiens avec Georges Charensol (1962) et Robert Mallet (1951)

(Vincennes, Fr.: Frémeaux \& Associés, 2007), audiobook, 1 disc.

39. Banham, The New Brutalism, 46.

40. Koolhaas, New York Délire, 294.

41. Diaz Moreno and Garcia Grinda, "Everyday Delights," 9.

42. Ibid., 11.

43. Ibid., 17.

44. Anne Lacaton, speech held at Conférence d'Anne Lacaton (Lacaton \& Vassal), BOZAR, Brussels, December 4, 2008.

45. Anne Lacaton and Jean-Philippe Vassal, "Structural Freedom, a Precondition for the Miracle," in Lacaton \& Vassal. Recent Work 2G N.60 (Barcelona: Editorial Gustavo Gili, 2012), 162-75.

46. Ibid., 162.

47. Ibid., 166.

48. Ibid.

49. Ibid.

50. Banham, The New Brutalism, 47.

51. Karine Dana, "On Lacaton \& Vassal: An Attempt at a Voiceover," in Lacaton \& Vassal.

Recent Work 2G N.60 (Barcelona: Editorial Gustavo Gili, 2012), 17.

52. Lacaton and Vassal, "Structural Freedom," 162.

53. Ibid.

54. Alison and Peter Smithson, "The Found and the 'As Found'," in The Independent Group: Postwar Britain and the Aesthetic of Plenty, ed. David Robbins (Cambridge MA, USA: The MIT Press, 1990), 201-202.

55. Alison Smithson, "Reappraisal of Concepts in Urbanism," Architectural Design, no. 7 (1974): 403-406.

56. Ilka and Andreas Ruby, 2G Libros. Lacaton \& Vassal (Barcelona: Editorial Gustavo Gili, 2007), 144.

57. Ibid., 145.

58. Alejandro Aravena, "Quinta Monroy," $A R Q$, no. 57 (July 2004): 30-33.

59. Ibid., 30. 
60. Camillo Boano and Francisco Vergara Perucich, "Bajo escasez. ¿Media casa basta?”, Revista de Arquitectura 21, no. 31 (November 2016): 41. (English translation from the authors available at: http://www.zeroundicipiu.it/wpcontent/uploads/2016/04/VV04_ ENG_091.pdf).

61. Banham, The New Brutalism, 47.

62. Olivier Namias, "Robin des Boîtes," Le Monde diplomatique, March 2016.

63. Aravena, "Quinta Monroy," 31.

64. Vandeputte, "Economy and Excess," 110.

\section{References}

Aravena, Alejandro. "Quinta Monroy." $A R Q$, no. 57 (July 2004).

Banham, Reyner. The New Brutalism: Ethic or Aesthetic? London: Reinhold Publishing Corporation, 1966.

Boano, Camillo, and Francisco Vergara Perucich. "Bajo escasez. ¿Media casa basta?” Revista de Arquitectura 21, no. 31 (November 2016).

Dana, Karine. "On Lacaton \& Vassal: An Attempt at a Voiceover." In Lacaton \& Vassal. Recent Work 2G N.60. Barcelona: Editorial Gustavo Gili, 2012.

Diaz Moreno, Cristina, and Efren Garcia Grinda. "Everyday Delights. A Conversation with Anne Lacaton and Jean Philippe Vassal." El Croquis, no.177/178 (2015).

Guth, Sabine, Jean-Michel Léger and François-Xavier Trivière. "Dix ans après, la leçon de la cité-manifeste à Mulhouse." AMC, no. 227 (October 2013).

Hansen, Oscar. "La forme ouverte dans l'architecture - l'art du grand nombre." Le Carré Bleu, no. 1 (1961).

Havik, Klaske, Véronique Patteeuw, and Hans Teerds. "Editorial, Productive Uncertainty/ Indeterminacy in Spatial Design, Planning and Management." OASE no. 85 (2011).

Hughes, Jonathan. "The Indeterminate Building." In Non-Plan: Essays on Freedom, Participation and Change in Modern Architecture and Urbanism, edited by Jonathan Hughes and Simon Sadler, 90-103. Oxford, UK: Oxford Architectural Press, 2000.

Johnson, Philip. "School at Hunstanton, Norfolk." Architectural Review, 1954.

Koolhaas, Rem. New York Délire. Marseille, Fr.: Editions Parenthèses, 2002; or. ed. Delirious New York. Oxford, UK: Oxford University Press, 1978.

Lacaton, Anne. Speech held at Conférence d'Anne Lacaton (Lacaton \& Vassal), BOZAR, Brussels, December 4, 2008.

- - , and Jean-Philippe Vassal. "Structural Freedom, a Precondition for the Miracle." In Lacaton \& Vassal. Recent Work 2G N.60. Barcelona: Editorial Gustavo Gili, 2012.

Le Corbusier. Entretiens avec Georges Charensol (1962) et Robert Mallet (1951). Vincennes, Fr.: Frémeaux \& Associés, 2007. Audiobook, 1 disc.

Llewelyn Davies, Richard. "Endless Architecture." Architectural Association Journal, no. 67 (1951).

Lucan, Jaques. Précisions sur un état présent de l'architecture. Lausanne, Switz.: Presses polytechniques et universitaires romandes, 2015.

Merleau-Ponty, Maurice. L'CEil et l'esprit. Paris: Gallimard, 2002; first ed., 1964.

Namias, Olivier. "Robin des Boîtes." Le Monde diplomatique, March 2016.

Negri, Antonio, and Michael Hardt. Multitude: Guerre et démocratie à l'âge de l'Empire. Paris: La Découverte, 2004.

Risselada, Max, and Dirk van den Heuvel, eds. Team X 1953-1981, in Search of a Utopia of the Present. Rotterdam, The Neth.: NAI Publishers, 2005.

Ruby, Ilka and Andreas. 2G Libros. Lacaton \& Vassal. Barcelona: Editorial Gustavo Gili, 2007.

Smithson, Alison. "The Violent Consumer, or Waiting for the Goodies." Architectural Design, no. 5 (1974).

Smithson, Alison and Peter. "The Aesthetics of Change." Architects' Year Book. Vol. 8. London: Elek Books, 1957.

- - . Ordinariness and Light: Urban Theories 1952-1960 and Their Application in a Building Project 1963-1970. Cambridge MA, USA: The MIT Press, 1970.

Stirling, James. "Regionalism and Modern Architecture." Architects' Year Book. Vol. 8. London: Elek Books, 1957. 
van den Heuvel, Dirk. "Team Ten Diagrams." Daidalos, no. 74 (2000).

Voelcker, John. "D'Aix-en-Provence à Oterlo ou l'agonie et la mort du C.I.A.M." Le Carré

Bleu 41959 Feuille internationale d'architecture. Paris: Le Carré Bleu, 1959.

Weeks, John. "Indeterminate Architecture." The Transactions of the Bartlett Society 2 (19631964).

Thompson, D'Arcy Wentworth. On Growth and Form. 2nd ed. Cambridge, UK: Cambridge University Press, 1942; or. ed. (Cambridge, UK: Cambridge University Press, 1917).

\section{Credits}

Xavier Van Rooyen graduated in architecture from the School of Architecture in Liège (Belgium). He has practiced architecture for many years, as an assistant architect first, for JDS architects and Pierre Hebbelinck and then through his own office, where he worked on several public commissions. He joined the Department of Architectural Design at ULiège as an Assistant Professor in 2012, where currently, he develops his ongoing Ph.D. with Jacques Lucan, author of Composition, Non-composition (2012), and Bernard Kormoss. E-mail: xvanrooyen@uliege.be

Michaël Bianchi graduated in architecture from the School of Architecture in Liège (Belgium). He has practiced architecture for many years as a partner of the office L'Escaut in Brussels. He joined the Department of Architectural Design at ULiège as an Assistant Professor in 2013 and teaches architectural design studio. E-mail: mbianchi@uliege.be 